\title{
AKTIVITAS DAKWAH GERAKAN SALAFI PADA MASA PANDEMI COVID-19
}

\author{
Jeudi Aneigia Branchais \\ Program Studi S1 Sosiologi dari Fakultas Ilmu Sosial dan Hukum \\ Universitas Negeri Surabaya (UNESA) \\ jeudi.18028@mhs.unesa.ac.id \\ Agus Machfud Fauzi \\ Program Studi S1 Sosiologi dari Fakultas Ilmu Sosial dan Hukum \\ Universitas Negeri Surabaya (UNESA) \\ agusmfauzi@unesa.ac.id
}

DOI: 10.46781/al-mutharahah.v18i1.225

\begin{abstract}
Da'wah is an activity that is needed by Muslims, it is a means of conveying Islamic teachings. During the current COVID-19 (Coronavirus Disease) pandemic, da'wah activities have undergone a massive evolution in the public space. This condition is a challenge for da'I and mad'u. This implication is also experienced by followers of the salafi movement. The implementation of preaching, which was originally cultured face to face, changed to screen to screen which massively demanded rapid adaptation. This study aims to explore the symptoms in the salafi da'wah phenomenon carried out online during the COVID-19 pandemic. Through a phenomenological approach, this study investigates pure symptoms that are independent of the intervention. Using qualitative methods, it is known that the salafi movement makes use of information technology in preaching activities. The salafi movement applies the concept of eda'wah, namely using whatsapp lectures, zoom, google meet, streaming youtube, podcast, clubhouse, twitter, telegram and others. Not only in the da'wah program, this activity is also carried out in the Al-Qur'an tahfidz program and joint charity.
\end{abstract}

Keywords: Da'wah, Salafi movement, Pandemic COVID-19

\begin{abstract}
Abstrak
Dakwah merupakan aktivitas yang sangat dibutuhkan oleh umat islam, dakwah menjadi sarana dalam menyampaikan ajaran islam. Pada masa pandemi COVID-19 (Coronavirus Disease) saat ini, aktivitas dakwah mengalami evolusi yang massif dalam ruang publik. Kondisi ini menjadi tantangan tersendiri bagi da'I dan mad'u. Implikasi tersebut dialami pula oleh para pemeluk gerakan salafi. Penyelenggaraan dakwah yang semula berbudaya face to face berubah menuju screen to screen yang secara massif menuntut adaptasi secara cepat. Penelitian ini bertujuan untuk menggali gejala dalam fenomena dakwah salafi yang dilaksanakan secara daring pada masa pandemi COVID-19. Melalui pendekatan fenomenologi, penelitian ini menyelidiki gejala murni yang terlepas dari intervensi. Menggunakan metode kualitatif, diketahui bahwa gerakan salafi memanfaatkan teknologi informasi dalam kegiatan dakwah. Gerakan salafi menerapkan konsep e-dakwah, yakni menggunakan kuliah whatsapp, zoom, google meet, streaming youtube, podcast, clubhouse, twitter, telegram dan lain-lain. Tidak hanya dalam program dakwah, aktivitas ini juga dilakukan pada program tahfidz Al-Qur'an dan amal bersama.
\end{abstract}

Kata Kunci: Dakwah, Gerakan salafi, Pandemi COVID-19 


\section{A. Pendahuluan}

Gerakan dakwah salafi merupakan salah satu kelompok gerakan Islam yang lahir di tahun 1980-an. Ide yang disandarkan oleh gerakan ini merujuk pada diskursus salaf, yang berarti "telah lalu". Salafi merujuk pada gerakan purifikasi agama. Gerakan salafi muncul di Arab Saudi yang menandakan perang terhadap bid'ah, takhayul, syiriik, serta menjadikan Al-Qur'an dan Sunnah, sumber hukum utama ${ }^{2}$.

Gerakan Selafi menggiring semua muslim untuk kembali berpedoman, pada AlQur'an dan as Sunnah. Senada dengan hal tersebut, dakwah yang dilakukan oleh gerakan Salafi mengembalikan semua keputusan pada Al-Qur'an dan as Sunnah, dengan mengikuti pendapat beberapa ulama Salaf al-Shaykh. Ulama Salaf al-Shaykh diantaranya, Ibn Taimiyah (1263-1328), Ibn Qayyim al-Jauziyah (1292- 1350), Husein al-Dzahabi (12841348), Ibn, Katsir (1300-1373), Muhammad bin Abdul Wahhab (1703-1792), dan cendekiawan modern, seperti Abdul,Aziz Bin Baz (1912- 1999), dan Muhammad Nashiruddin al-Albani (1914-1999) ${ }^{3}$.

Di Indonesia, gerakan salafi hadir sebelum lengsernya presiden Soeharto. Gerakan salafi lebih pesat bergerak tepat di era Reformasi. Didirikannya yayasan di beberapa wilayah, gerakan Salafi di Indonesia mengorganisir kelompok kajian Islam. Hingga yang paling fenomenal, gerakan Salafi mendirikan Laskar Jihad (pasukan militer) ${ }^{4}$.

Gerakan Salafi di Indonesia membangun setiap aktivitas dakwah dengan berlandasakan prinsip-prinsip, diantaranya menegakkan keutamaan Sunnah nabi, menginterpretasikan contoh kepada masyarakat, dan mendorong pemurnian tauhid. Sedangkan tujuan dakwah dikemukakan oleh Ja'far Umar,Thalib terdiri dari 4 yaitu pertama, memberikan pengetahuan yang lengkap guna menjawab segala permasalahan dalam kehidupan. Kedua, memberi titik tengah pada penyimpangan pemahaman kaum Muslim dari bid'ah dan kufur. Ketiga, senantiasa meghidupkan amalan yang dilaksanakan oleh Rasulullah. Keempat, menumbukan kesatuan umat Muslim, kecintaan pada Sunnah Rasulullah, serta menjauhkan dari bid'ah dan kufur ${ }^{5}$.

Sebagai usaha mencapai keempat tujuan tersebut dibutuhkan sebuah metode atau strategi dakwah bagi gerakan salafi. Untuk menyebarkan prinsip-prinsip di atas, gerakan salafi menggunakan, dua metode yakni daurah dan halaqah. Daurah merupakan pelatihan yang dilaksanakan di waktu dan tempat yang telah disepakati. Sedangkan halaqah ialah kegiatan bersama yang dilaksanakan, dengan tujuan mempelajari ilmu islam. Kegiatan halaqah dipimpin oleh seorang uztadz atau ustadzah.

Metode dakwah yang digunakan oleh gerakan salafi didominasi oleh, kegiatan secara bersama-sama (memicu adanya kerumunan). Jika aktivitas tersebut dilakukan pada situasi saat ini dapat melanggar peraturan pemerintah. Merebaknya Coronavirus Disease atau COVID-19 saat ini telah membawa perubahan pola hidup seluruh umat di dunia. Penularan virus COVID-19 yang tidak dapat ditebak, mengakibatkan munculnya pelarangan dalam kegiatan yang melibatkan keramaian. Dengan diterapkannya social distancing, pemerintah berupaya menekan penyebaran wabah ini. Kondisi ini telah

1 Yazid bin Abdul Qadir Jawas, "Mulia Dengan Manhaj Salaf," Journal of Chemical Information and Modeling 53, no. 9 (1981): 1689-99.

${ }^{2}$ Abd. Rachman Assegaf, "Gerakan Transnasional Islam Dan Globalisasi Salafi Di Islamic Center Bin Baz Yogyakarta," Millah 16, no. 2 (2017): 147-72.

${ }^{3}$ Sabine Damir-Geilsdorf, Mira Menzfeld, and Yasmina Hedider, "Interpretations of Al-Wala' Wa-I-Bara' in Everyday Lives of Salafis in Germany," Religions 10, no. 2 (2019): 1-18, https://doi.org/10.3390/rel10020124.

${ }^{4}$ Noorhaidi Hasan, Laskar Jihad: Islam, Militansi, Dan Pencarian Identitas Di Indonesia Pasca Orde Baru, LP3ES (Jakarta: LP3ES, 2008), http://dx.doi.org/10.1016/j.appdev.2016.03.001\%250Ahttps://www.bertelsmannstiftung.de/fileadmin/files/BSt/Publikationen/GrauePublikationen/MT_Globalization_Report_2018.pdf\%250Ah ttp://eprints.Ise.ac.uk/43447/1/India_globalisation\%252C society and inequali.

${ }^{5}$ Hasan. 
menciptakan budaya baru, hampir seluruh kegiatan manusia dilaksanakan secara daring dengan memanfaatkan teknologi yang kian berkembang. Sekolah, bekerja, berdagang, hingga kegiatan pengajian dan forum keramaian lainnya tidak diperkenankan untuk mengadakan aktivitas secara tatap muka/offline ${ }^{6}$. Akibatnya, aktivitas dakwah gerakan salafi mengalami berbagai perombakan. Daurah dan halaqah yang biasanya dilakukan di masjid, aula, rumah ustadz, hingga di berbagai lembaga pendidikan harus disesuaikan dengan kondisi pandemi saat ini. Mulai dari media hingga waktu yang digunakan saat aktivitas dakwah diadakan harus senantiasa disesuaikan dengan kondisi saat ini. Oleh karena itu, peneliti bermaksud untuk mengidentifikasi aktivitas dakwah gerakan Salafi pada masa pandemi COVID-19.

Terdapat beberapa penelitian terdahulu yang relevan dengan penelitian ini. Muhammad Ali Chozin (2013) berjudul "Strategi Dakwah Salafi di Indonesia". Penelitian ini mengidentifikasi strategi dakwah salafi di Indonesia. Hasil daripada penelitian ini adalah gerakan salafi mendirikan lembaga-lembaga seperti yayasan, sekolah, rumah sakit, pondok pesantren, dan lembaga kursus bahasa Arab. Pendirian sarana tersebut bertujuan untuk menunjang eksistensi dakwah Salafi. Selain itu, tokoh-tokoh salafi juga menjadi pengisi dalam berbagai acara kegamaan seperti khotbah, halaqah, daurah, tabligh akbar, dll.

Dady Hidayat (2012) yang berjudul "Gerakan Dakwah Salafi di Indonesia pada Era Reformasi". Hasil penelitian menunjukkan bahwa gerakan Salafi ditopang oleh berbagai yayasan. Pada setiap elemen gerakan ini sarat akan otonomi. Tidak dijumpai jenjang hirarkis yang mengatur organisasi dalam gerakan Salafi. Tepat pada era reformasi, gerakan ini menyebarkakan ideologi secara bebas dan terbuka.

Dua penelitian diatas beserta penelitian lain yang menjadi referensi diatas cenderung menunjukkan ekspansi dakwah gerakan salafi. Beberapa diketahui mengambil fokus pada tokoh yang aktif dalam gerakan dakwah tersebut. Strategi maupun metode yang dijelaskan hanya sebatas pengetahuan umum. Oleh sebab itu, penelitian ini mengambil posisi berbeda dari dua penelitian sebelumnya, yakni fokus pada strategi dakwah pada masa pandemi. Penelitian kali ini akan mengidentifikasi secara terperinci bagaimana proses dakwah yang diadakan secara screen to screen atau online.

\section{B. Metode Penelitian}

Penelitian ini menggunakan metode kualitatif yakni menggambarkan dan meringkas seluruh aspek dari penelitian yang dimakud. Penelitian kualitatif menurut Lexy J.Moleong (2014) merupakan penelitian yang dimaksud untuk memahami sesuatu yang dialami oleh subyek penelitian. Persepsi, perilaku, tindakan, motivasi secara holistik menjadi ranah penelitian kualitatif.

John W. Cresswell menggambarkan metode kualitatif sebagai proses investigasi. Peneliti dapat memahami fenomena secara bertahap. Tahapan tersebut diantaranya membedakan, membandingkan, meniru, mengkatalogkan, serta mengelompokkan objek studi. Melalui metode kualitatif, realitas empirik dibalik sebuah fenomena dapat diketahui secara mendalam, rinci, dan tuntas. Penelitian ini bertujuan untuk menggali gejala dalam fenomena dakwah salafi yang dilaksanakan secara daring pada masa pandemi COVID-19. Oleh karena itu, metode penelitian kualitatif dipilih guna mendapatkan fakta-fakta dari setiap fenomena yang ditampilkan secara apa adanya.

Untuk mendukung proses pencarian data, peneliti menggunakan pendekatan fenomenologi. Edmund Husserl memaknai fenomenologi sebagaimana melihat.kebenaran sesuatu dari hal.sebaliknya. Tujuan dari fenomenologi ialah kembali pada realitanya sendiri. Secara lebih sederhana, penelitian fenomenologi berupaya untuk mengklarifikasi

\footnotetext{
${ }^{6}$ Anugrah Nur Fitrah, “Media Sebagai Sarana Dakwah Dimasa," IAIN Parepare, n.d.
} 
situasi yang dialami subyek penelitian ${ }^{7}$. Dalam misi mencari esensi dari sebuah fenomena, peneliti senantiasa menjauh dari asumsi, praduga, dan prasangka. Sehingga dapat diperoleh data yang akurat.

Data diambil dengan menggunakan teknik wawancara dan dokumentasi. Informan dalam wawancara diambil dari keanggotaan Salafi (khususnya dari Masjid Nidaul Fitrah). Untuk menunjang data primer yang dilaksanakan melaui teknik wawancara, peneliti juga mengambil data sekunder. Data sekunder diperoleh dari e-book, artikel jurnal, thesis atau dissertation, dll.

\section{Pembahasan}

\section{Gerakan Salafi di Indonesia}

Salafi berasal dari kata "salaf" Hisyam Salaf Al-Shahih, yakni generasi muslim ketiga paling awal mengemukakan istilah tersebut diambil dari salafa yaslufu salfan yang artinya "telah lalu". Secara istilah kata "salaf" merujuk pada sifat khusus para sahabat ${ }^{8}$. Jadi, salafi adalah kaum yang hidup setelah 300 tahun meninggalnya Nabi Muhammad SAW.

Gerakan salafi juga didefinisikan sebagai kelompok yang menerapkan metode masa lampau. Gerakan ini memegang pendapat dari ulama-ulama Salaf As-Shahih. Para ulama tersebut mengajarkan akidah, fikih, adab, dan lain-lain. Senada dengan hal tersebut, Matin (2017) mengemukakan definisi "salafiyah" yakni, seruan kepada umat muslim untuk kembali pada sumber utama atau asli. Dengan tujuan kebangkitan Islam sebagai benteng pertahanan dari bentuk-bentuk hegemoni dunia barat. Upaya yang dilakukan ialah dengan mengembalikan model Islam yang terbaik dalam 3 masa.

Menjalankan dakwahnya, gerakan salafi meyakini manhaj yakni gerakan yang memiliki satu pemikiran untuk menghidupkan kembali ajaran Islam yang murni dengan landasan Al-Qur'an dan As-Sunnah. Hal ini dimaksudkan pada amalan-amalan tokoh terdahulu? .

Gerakan salafi mulanya terbentuk di negara Arab Saudi. Dakwah salafi seringkali mendapat dukungan resources dari beberapa negara di Kawasan Teluk. Sebab, salafi tidak dapat terlepas dari kampanye Arab Saudi yang mendorong wahhabi sasi muslim. Hal ini bertujuan untuk mengantisipasi meluasnya syi'ah pasca revolusi Iran (1979). Oleh karena itu, Arab Saudi sangat ambisius dalam melakukan dakwah ajaran wahhabi termasuk di Indonesia ${ }^{10}$.

Gerakan asal Timur Tengah ini hadir di Indonesia pada tahun 1980, dengan mengusung ide kebangkitan Islam. Eksistensi salafi di Indonesia mencapai puncak sejak lengsernya presiden Soeharto. Di Indonesia, gerakan salafi memberi warna baru pada aktivisme Islam di Indonesia. Meskipun, gerakan salafi menunjukkan identitas yang beda, serta ambisi besar terhadap "Islam murni"11.

Di Indonesia, gerakan salafi mendapatkan keleluasaan ketika era reformasi. Kegiatan ekspansi dakwah dengan berbagai media memudahkan mereka, terlebih tidak ada kecemasan akan represi dari kelompok dominan. Dukungan terhadap dakwa salafi terlihat dari kondisi struktural. Hal ini dibuktikan dengan lahirnya para aktor (ustad)

\footnotetext{
${ }^{7}$ Hardiansyah, "Teori Pengetahuan Edmund Husserl," Jurnal Substantia 15, no. 2 (2013): 228-38.

8 Damir-Geilsdorf, Menzfeld, and Hedider, "Interpretations of Al-Wala' Wa-I-Bara' in Everyday Lives of Salafis in Germany."

${ }^{9}$ N S Sufi, “Gerakan Salafi Di Perumahan Istana Candi Mas Regency Ngampelsari Candi Sidoarjo," UIN Sunan Ampel, 2019, 1-74, http://digilib.uinsby.ac.id/id/eprint/34693.

${ }^{10}$ M. Imdudin Rahmat, Arus Baru Islam Radikal: Transmisi Revivalisme Islam Timur Tengah Ke Indonesia. (Jakarta: Erlangga, 2005).

${ }^{11}$ Hasan, Laskar Jihad: Islam, Militansi, Dan Pencarian Identitas Di Indonesia Pasca Orde Baru.
} 
yang menajdi pemandu dalam menyampaikan materi dakwah. Aktor tersebut dipilih atas pengalaman atau latar belakang mereka seperti, lulusan asal universitas di Timur Tengah, LIPIA, maupun lulusan pesantren salafi di Indonesia ${ }^{12}$.

Pada tahun 1990, gerakan salafi mengibarkan sayapnya dengan dibangunnya beberapa yayasan. Yayasan-yayasan tersebut mendapat dukungan finansial dari Arab Saudi, Kuwait, dan lain-lain. Beberapa yayasan gerakan salafi terdapat pada tabel 1 .

Tabel 1. Daftar yayasan gerakan salafi di Indonesia

\begin{tabular}{|l|l|}
\hline \multicolumn{1}{|c|}{ NAMA YAYASAN } & \multicolumn{1}{c|}{ LOKASI } \\
\hline Majelis Ihya Turats as Islami & Yogyakarta \\
\hline Yayasan Al Shofwa & Jakarta \\
\hline Lajnah al-Khairiyah al Musyakarah & Jakarta \\
\hline Yayasan Imam Al Bukhori & Solo \\
\hline Yayasan Nurusunnah & Semarang \\
\hline Wahdah Islamiyah & Sulawesi Selatan \\
\hline Yayasan Cahaya Ilmu & Jakarta \\
\hline Yayasan Al Huda & Bogor \\
\hline
\end{tabular}

Setiap yayasan memiliki berbagai kegiatan yang cenderung berbeda. Rahmat (2005), mengemukakan bahwa beberapa yayasan mendirikan lembaga pendidikan, mensponsori pembangunan masjid, kegiatan halaqoh dan daurah, serta kegiatan lainnya. Namun, diseluruh yayasan tetap memegang tujuan utama untuk melaksanakan dakwah ajaran islam murni.

Kegiatan dakwah sebelumnya diadakan secara tatap muka, baik itu dalam kelas maupun luar kelas. Pelaksanaan dipimpin oleh aktor yakni ustad ataupun ustadzah. Kegiatan cenderung melibatkan kerumunan, sebab tidak sedikit dari masyarakat yang antusias untuk hadir dalam kegiatan tersebut. Namun, ketika kondisi dunia sangat tidak mendukung menimbulkan masalah-masalah baru. Penyampaian dakwah yang dirombak secara total, hingga penundaan aktivitas dakwah.

2. Aktivitas Dakwah Salafi di Masa Pandemi COVID-19

Gerakan salafi melaksanakan setiap dakwahnya dengan berlandaskan tiga prinsip, yakni menegakkan Sunnah Nabi, memberi contoh, dan pemurnian tauhid ${ }^{13}$. Disisi lain, Ja'far Thalib mengemukakan tujuan dakwah salafi. Ia memberi empat poin penting sebagai tujuan dakwah salafi, diantaranya:

a. Memberi edukasi terkait pemahaman Islam dalam menjawab berbagai permasalahan kehiduan manusia;

b. Memberi jalan tengah terhadap berbagai penyimpangan pemahaman (aum bid'ah dan kufur);

c. Senantiasa menggiring kaum muslim untuk melaksanakan amalan yang diajarkan Rasulullah;

d. Menciptakan persatuan umat Islam, seta loyal terhadap Sunnah Rasulullah

Pasca tumbangnya rezim Soeharto, aktivitas dakwah Salafi mendapat kebebasan secara penuh. Sempat terbelenggu, gerakan salafi memanfaatkan kondisi untuk memperkuat eksistensi mereka. Hal ini dibuktikan dengan pendirian yayasan, pondok pesantren, tempat kursus bahasa Arab, rumah sakit, hingga penerbitan secara massif ${ }^{14}$.

${ }^{12}$ Dady Hidayat, "Gerakan Dakwah Salafi Di Indonesia Pada Era Reformasi," MASYARAKAT: Jurnal Sosiologi 17, no. 2 (2012), https://doi.org/10.7454/mjs.v17i2.3738.

${ }^{13}$ Hidayat.

${ }^{14}$ Muhammad Ali Chozin, "Strategi Dakwah Salafi Di Indonesia," Jurnal Dakwah XIV, no. 1 (2013): 1-25, http://ejournal.uin-suka.ac.id/dakwah/jurnaldakwah/article/view/273. 
Mereka juga memanfaatkan teknologi yang semakin canggih. Dalam pelaksanaan kegiatan, seringkali mereka dokumentasikan. Hal ini ditujukan sebagai bentuk laporan, kenang-kenangan, dan juga media dakwah. Media dakwah yang dimaksud yakni nantinya mereka akan bagikan melalui berbagai cara, seperti dibuat dalam bentuk kaset yang kemudian dijual, maupun dibagikan secara gratis diberbagai platform.

Strategi adat diadakan dalam keadaan dunia yang normal, yakni jauh dari wabah. Realitanya, saat ini dunia sedang berduka atas hadirnya wabah yang telah mengakibatkan perbuahan sosial hampir diseluruh aspek kehidupan. Adanya wabah dan tantangan di zaman millenial memaksa semua aspek untuk beradaptasi, termasuk proses dakwah ${ }^{15}$.

Kegiatan dakwah yang biasanya dilaksanakan secara tatap muka, saat ini berubah melalui berbagai perantara. Gerakan salafi hanya dapat mengandalkan teknologi dan diadakan secara daring. Hal tersebut didukung dengan hasil penelitian oleh Nurdin (2014), bahwa intensitas pengguna internet di kalangan muslim Indonesia dinyatakan tinggi. Oleh karena itu, banyak para ulama memanfaatkan ruang online untuk menyampaikan dakwah.

Dakwah secara online dinilai lebih efektif dan hemat biaya, serta dapat meningkatkan jumlah penonton. Meskipun ada sebagian orang yang tidak dapat bertahan untuk terus memperhatikan dakwah hingga usai ${ }^{16}$. Kondisi serupalah yang menjadi tantangan bagi gerakan dakwah salafi. Para da'i atau aktor yang terlibat tidak semua memiliki keahlian dalam hal teknologi. Jaringan, hingga relasi menjadi pokok pembahasan yang masih sering diperbincangkan.

Untuk mengatasi hal tersebut, telah dijumpai beberapa yayasan yang mengadakan dakwah secara online. Dakwah secara online ini juga masih terlaksana hingga saat ini. Seperti Yayasan Indonesia Bertauhid, mengadakan dakwah secara online yakni melalui aplikasi zoom atau meet, live youtube, live instagram, whatsapp, dan telegram. Yayasan Indonesia Bertauhid juga mengadakan tanya jawab online melalui twitter dan facebook. Tidak hanya itu, yayasan ini juga selalu memberi dakwah melalui poster yang kemudian dibagikan melalui feeds instagram.

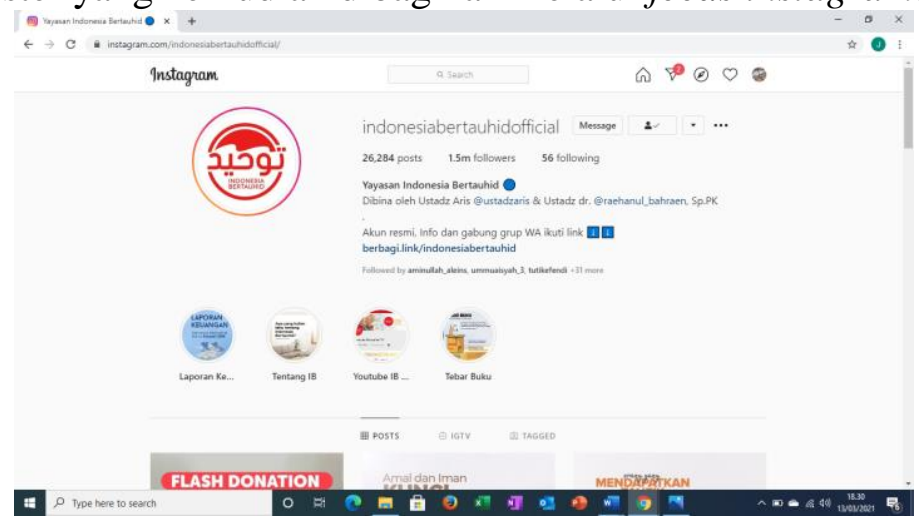

Gambar 1.

${ }^{15}$ Setyowati and Anggi Cahya, "Peran Dakwah Daring Untuk Menjaga Solidaritas Sosial Di Masa Pandemi Covid 19.," Academia Journal of Multidisciplinary Studies 4, no. 2 (2020): 295-310.

${ }^{16}$ Nurdin, "To Dakwah Online Or Not To Dakwah Online: Da'i Dilemma In Internet Age," Al-Mishbah Jurnal IImu Dakwah Dan Komunikasi 10, no. 1 (2014): 57-58. 


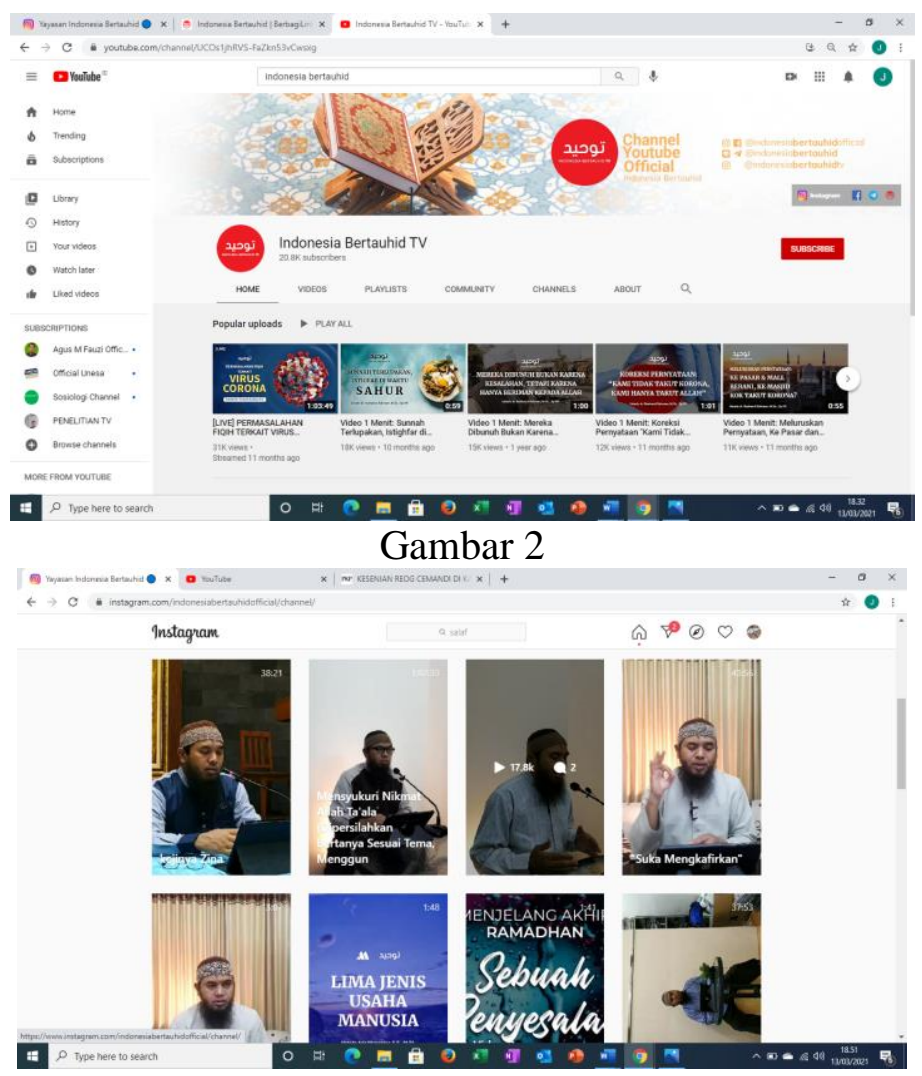

Gambar 3.

Hal serupa juga diterapkan oleh Yayasan Rumaysho, yakni yayasan yang didirikan oleh Muhammad Abduh Tuasikal. Namun, terdapat beberapa media baru yang digunakan oleh Yayasan Rumaysho. Media tersebut ialah podcast melalui radio atau channel Rumaysho dan aplikasi clubhouse. Hal ini sangat mendukung kaum millenial untuk berkontribusi. Sebab yayasan menggunakan aplikasi yang sedang tranding dan memanfaatkannya sebagai media dakwah.

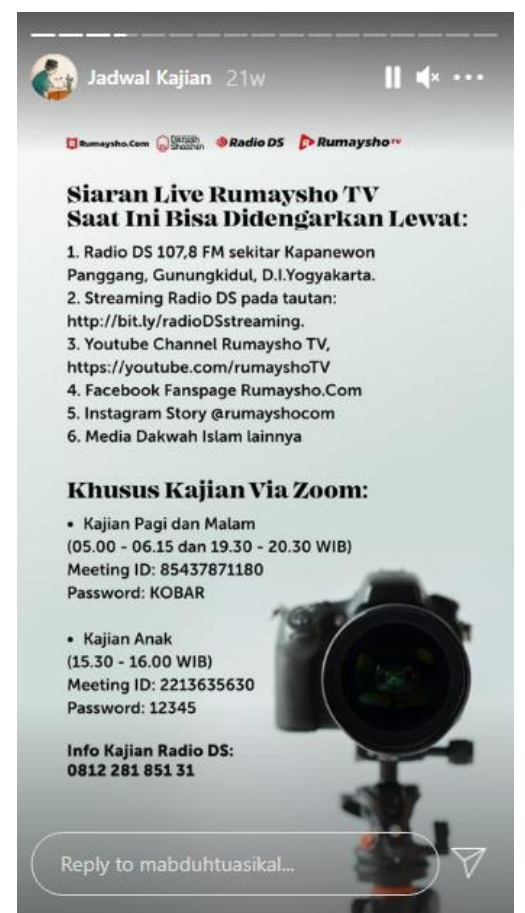

Gambar 4.
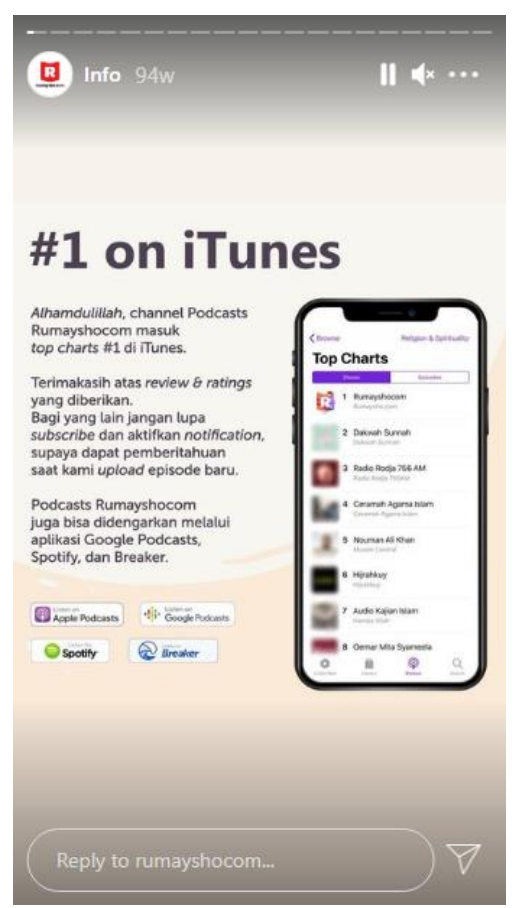

Gambar 5. 
Selain dua yayasan tersebut, beberapa ulama atau ustadz juga mengadakan kulwap atau kuliah whatsapp. Kuliah ini diadakan sesuai jadwal yang ditentukan dan diikuti oleh peserta yang telah mendaftarkan diri mereka. Materi yang disampaikan bervariatif. Hal ini untuk mengantisipasi kejenuhan para peserta. Beberapa diantaranya mengambil materi terkait kehidupan ditengah wabah besar. Namun, tidak menutup kemungkinan materi diluar itu disampaikan.

Selain dakwah, gerakan salafi juga menjadi salah satu pelopor kelompok mengaji. Sebelumnya, kelompok mengaji diadakan secara tatap muka baik bersamaan maupun individual dengan aktor salaf. Namun, dengan kondisi dunia yang memaksa semua aktivitas secara jarak jauh. Gerakan salafi menggunakan strategi daring, baik itu pengajian online maupun untuk para penghafal Al-Qur'an.

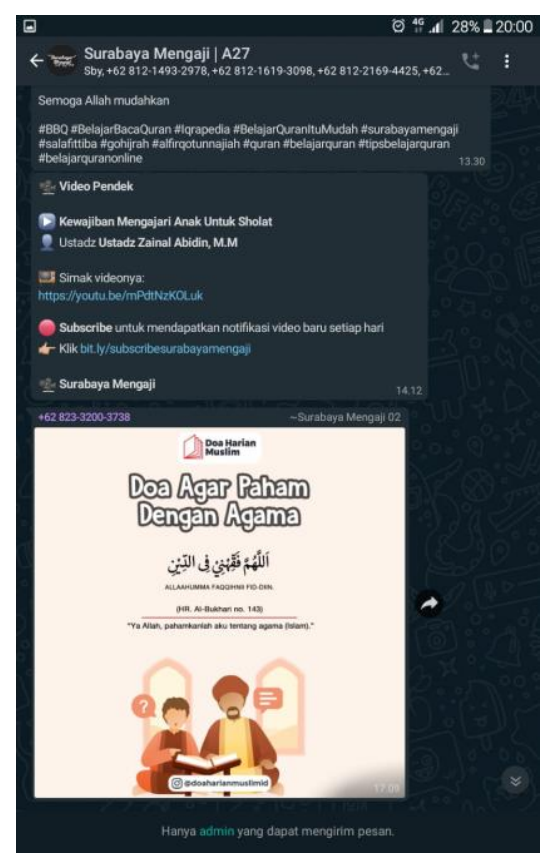

Gambar 6.

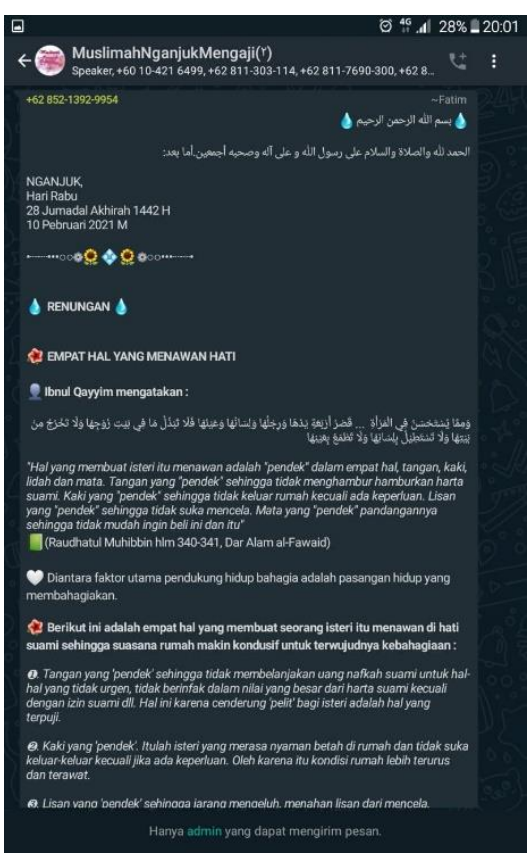

Gambar 7.

Kehadiran internet adalah media yang tidak dapat dihindari. Sebab, internet merupakan bentuk peradaban baru dalam dunia informasi dan komunikasi. Dilihat dari kacamata kondisi dunia saat khususnya di Indonesia, internet menjadi pahlawan atas segala aktivitas manusia. Dakwah secara daring menciptakan sikap interaktif antar da' $i$ dan mad'u.

Pesan-pesan terkait Islam murni dijelaskan tidak hanya melalui dakwah online. Namun, juga dengan membagikan berbagai informasi keislaman murni melalui poster atau gambar. Langkah yang diambil gerakan salafi dalam kondisi pandemi ini menjadi hal yang tepat untuk menjaga generasi muda pula ${ }^{17}$. Bentuk nyata atas tujuan ini ialah pembuatan jaringan-jaringan tentang Islam, seperti: cybermuslim or dakwah, situs dakwah, blog, dan lain sebagainya. Masing-masing jaringan juga memiliki fasilitas dan metode yang berbeda-beda.

Dalam pelaksanaannya, gerakan salafi memberikan kelonggaran para peserta untuk mengikuti kegiatan yang telah diselenggarakan. Kelompok salafi akan senantiasa memberi informasi terkait jadwal dakwah sekaligus tema yang akan dibahas. Mengingat bahwa dakwah online ini memiliki konsep "menembus batas ruang dan waktu", pihak penyelenggara tidak memaksakan kepada pihak manapun.

17 Efa Rubawati, "Media Baru: Tantangan Dan Peluang Dakwah," Jurnal Studi Komunikasi (Indonesian Journal of Communications Studies) 2, no. 1 (2018): 126-42, https://doi.org/10.25139/jsk.v2i1.510. 
Dalam penyampaian materi saat dakwah, da'i dituntut untuk senantiasa meningkatkan ketrampilan dan pengetahuan terkait teknologi indormasi dan komunikasi ${ }^{18}$. Hal ini merupakan salah satu upaya untuk menciptakan pelaksanaan dakwah yang menarikd an mudah dipahami. Telebih ini menggunakan jaringan internet, sehingga bagi para non-muslim secara terbuka diperbolehkan untuk bergabung dalam penyamapian dakwah maupun aktivitas yang diselenggarakan gerakan salafi lainnya.

\section{SIMPULAN}

Gerakan salafi merupakan kelompok agama Islam yang menegakkan satu pemikiran untuk menghidupkan kembali ajaran Islam murni, yakni berlandaskan Al-Qur'an dan AsSunnah. Kehadiran gerakan salafi di Indonesia pada tahun 1980, mulai berjaya pada era reformasi. Hal ini ditunjukkan dengan eksistensi yayasan salafi diberbagai wilayah di Indonesia. Tujuan utama didirikannya yayasan salafi, tidak lain adalah untuk memfasilitasi proses dakwah salafi di Indonesia.

Pasca rezim Soeharto, gerakan salafi memiliki kebebasan untuk melaksanakan dakwahnya. Dukungan teknologi di era moderen, telah mempermudah proses dakwah islam murni ini, khususnya pada masa pandemi Covid-19. Dalam kondisi tersebut, proses dakwah salafi di Indonesia harus beriringan dengan teknologi dan informasi. Ruang online (internet) menjadi media dakwah salafi saat ini. Dengan memanfaatkan youtube, instagram, twitter, facebook, clubhouse, whatsapp, telegram, dan berbagai aplikasi atau platform lainnya, gerakan salafi berupaya untuk tetap melaksanakan dakwahnya.

Dibalik efektivitas dan efisiensi pelaksanaan dakwah secara screen to screen. Aktivitas dakwah salafi pada masa pandemi Covid-19, memerlukan keahlian dalam bidang teknologi dan informasi. Kebutuhan tersebut tidak sepenuhnya dimiliki oleh da'i maupun penonton. Adapun faktor penghambat proses dakwah lainnya, yakni kesulitan memperoleh jaringan internet yang kuat dan alat komunikasi yang kurang memadai.

\section{DAFTAR PUSTAKA}

Assegaf, Abd. Rachman. "Gerakan Transnasional Islam Dan Globalisasi Salafi Di Islamic Center Bin Baz Yogyakarta." Millah 16, no. 2 (2017): 147-72.

Chozin, Muhammad Ali. "Strategi Dakwah Salafi Di Indonesia." Jurnal Dakwah XIV, no. 1 (2013): 1-25. http://ejournal.uin-suka.ac.id/dakwah/jurnaldakwah/article/view/273.

Damir-Geilsdorf, Sabine, Mira Menzfeld, and Yasmina Hedider. "Interpretations of Al-Wala' Wa-1-Bara' in Everyday Lives of Salafis in Germany." Religions 10, no. 2 (2019): 1-18. https://doi.org/10.3390/rel10020124.

Fitrah, Anugrah Nur. "Media Sebagai Sarana Dakwah Dimasa." IAIN Parepare, n.d.

Hardiansyah. "Teori Pengetahuan Edmund Husserl." Jurnal Substantia 15, no. 2 (2013): 22838.

Hasan, Noorhaidi. Laskar Jihad: Islam, Militansi, Dan Pencarian Identitas Di Indonesia Pasca Orde Baru. LP3ES. Jakarta: 2008. http://dx.doi.org/10.1016/j.appdev.2016.03.001\%250Ahttps://www.bertelsmannstiftung.de/fileadmin/files/BSt/Publikationen/GrauePublikationen/MT_Globalization_Re port_2018.pdf\%250Ahttp://eprints.1se.ac.uk/43447/1/India_globalisation\%252C society and inequali.

Hidayat, Dady. "Gerakan Dakwah Salafi Di Indonesia Pada Era Reformasi." MASYARAKAT: Jurnal Sosiologi 17, no. 2 (2012). https://doi.org/10.7454/mjs.v17i2.3738.

Nurdin. "To Dakwah Online Or Not To Dakwah Online: Da'i Dilemma In Internet Age." Al-

${ }^{18}$ Nurdin, "To Dakwah Online Or Not To Dakwah Online: Da'i Dilemma In Internet Age." 
Mishbah Jurnal Ilmu Dakwah Dan Komunikasi 10, no. 1 (2014): 57-58.

Rahmat, M. Imdudin. Arus Baru Islam Radikal: Transmisi Revivalisme Islam Timur Tengah Ke Indonesia. Jakarta: Erlangga, 2005.

Rubawati, Efa. "Media Baru: Tantangan Dan Peluang Dakwah." Jurnal Studi Komunikasi (Indonesian Journal of Communications Studies) 2, no. 1 (2018): 126-42. https://doi.org/10.25139/jsk.v2i1.510.

Setyowati, and Anggi Cahya. "Peran Dakwah Daring Untuk Menjaga Solidaritas Sosial Di Masa Pandemi Covid 19." Academia Journal of Multidisciplinary Studies 4, no. 2 (2020): 295-310.

Sufi, N S. "Gerakan Salafi Di Perumahan Istana Candi Mas Regency Ngampelsari Candi Sidoarjo." UIN Sunan Ampel, 2019, 1-74. http://digilib.uinsby.ac.id/id/eprint/34693.

Yazid bin Abdul Qadir Jawas. "Mulia Dengan Manhaj Salaf.” Journal of Chemical Information and Modeling 53, no. 9 (1981): 1689-99. 